\title{
Cells containing IgA subclasses in bronchi of subjects with and without chronic obstructive lung disease
}

\author{
D BURNETT,${ }^{*} \dagger$ J CROCKER, $\ddagger$ R A STOCKLEY* \\ From The *General Hospital, Birmingham, the $\ddagger$ Department of Pathology, East Birmingham Hospital, and the \\ $\dagger$ Department of Immunology, University of Birmingham
}

SUMMARY Necropsy specimens were obtained from the lungs of 10 subjects who had no history of lung disease, 10 who had died with chronic bronchitis, and 10 with bronchiectasis. Tissue sections were stained for IgA1 or IgA2 using the immunoperoxidase technique, and the number of cells in the bronchi stained for these proteins was counted. The total number of $\operatorname{IgA}$ positive cells was increased in bronchitic and bronchiectatic lungs compared with those from control subjects. The number of IgA2 positive cells was similar in those with bronchitis and bronchiectasis and significantly higher than in controls. Similarly, cells containing IgA1 were increased in the lungs of subjects with chest disease but were higher in those with bronchitis than in those with bronchiectasis. The proportion of $\operatorname{IgA2}$ :total IgA containing cells was similar in sections from controls (mean (SD) $25(5.0) \%$ ) and those with bronchiectasis (mean (SD) 24 (4)\%), but lower in those with bronchitis (mean (SD) $19(5 \cdot 0) \%$ ). The results show that cells containing IgAl predominate in the major bronchi but that the proportion of cells containing $\operatorname{IgA} 2$ is higher than in non-mucosal lymphoid tissues. Bronchitis and bronchiectasis are associated with greater numbers of cells producing $\operatorname{IgA}$ in the bronchi, and this is consistent with increased local production of $\operatorname{IgA}$ in the lung secretions of bronchitic subjects.

Immunoglobulin $\mathrm{A}$ (IgA) is thought to protect the respiratory tract from infection by pathogens. ${ }^{1}$ It is the most abundant immunoglobulin class in lung secretions, unlike the blood plasma, where IgG predominates. ${ }^{2}$ Most (about $90 \%$ ) of the blood $\operatorname{IgA}$ is monomeric ${ }^{3}$; in lung secretions about $50-70 \%$ is present as polymeric IgA and most of this is secretory $\operatorname{IgA},{ }^{45}$ indicating active secretion of polymeric $\operatorname{IgA}$ by secretory component mediated transport. ${ }^{6}$ Furthermore, although $10-20 \%$ of blood $\operatorname{IgA}$ is of the $\operatorname{IgA} 2$ subclass, the proportion of $\operatorname{IgA} 2$ is higher in lung secretions, representing about $30 \%$ of the total IgA. ${ }^{7}$ These observations, showing differences in the IgA composition of blood and lung secretions suggest that most lung $\operatorname{IgA}$ is produced locally within pulmonary tissues, although some is also derived from the blood by transudation. ${ }^{8}$

IgA plasma cells are most abundant in the glands and lamina propria of the major bronchi, suggesting

Accepted for publication 16 April 1987 that most of the IgA in lung secretions is produced in the upper airways, although some IgA plasma cells have also been seen in the small bronchi, bronchioles, and alveolar septa. ${ }^{910}$

The factors which influence local synthesis of $\operatorname{IgA}$ in the lung are poorly understood. It has been proposed, on the basis of indirect methods, that deficient local IgA production may be responsible for recurrent infection and morbidity in chronic bronchitis. ${ }^{911}$ This concept of "local deficiency" was supported by the report of reduced numbers of IgA plasma cells in the bronchi of bronchitics. ${ }^{9}$ The assessment of local IgA synthesis, however, is difficult in the presence of lung inflammation, as transudation of proteins including IgA from the plasma is increased. ${ }^{8}$ Recent studies measuring secretory $\operatorname{IgA}$ or polymeric $\operatorname{IgA}$ in the lung secretions from patients with chronic bronchitis have shown a significant increase in the amounts of these locally produced components of IgA during infective exacerbations. ${ }^{41213}$ These results showed that most subjects with chronic bron- 
chitis were capable of producing more IgA locally in response to local bacterial infection.

In view of these findings the present study was designed to reinvestigate, by immunohistochemistry, the numbers of plasma cells producing $\operatorname{IgA}$ in the bronchi of subjects with chronic obstructive lung disease. We wished to determine whether a study of the number of cells containing IgA in the bronchi of subjects with chronic bronchitis supported the hypothesis of local deficiency of IgA plasma cells or, alternatively, whether it suggests a competent bronchial IgA system. We also compared the results with those from subjects with bronchiectasis, a chronic lung condition characterised by continual lung infection. Specifically, plasma cells containing the $\operatorname{IgA} 1$ or $\operatorname{IgA} 2$ subclasses were counted to establish the proportion of cells containing these proteins and the influence of chronic lung disease on their distribution.

\section{Material and methods}

\section{LUNG TISSUE}

Necropsy tissue specimens were obtained within eight hours of death from 10 subjects (age range 27-81 years, mean 57), who had no recent history or pathological evidence of acute or chronic lung disease; from 10 subjects (64-83 years, mean 71 ) who had died with clinical and postmortem evidence of bronchiectasis, originating from a viral infection in childhood; and from 10 subjects (59-83 years, mean 65 ) who had died with chronic bronchitis. Four of these last group of subjects had died of their bronchitis and six had "incidental" bronchitis which did not cause their deaths. Histological diagnoses were made using the criteria of Dunnill. ${ }^{14}$ Necropsy tisse was considered to be appropriate for this study as we have shown previously that IgA staining of bone marrow cells seen in necropsy specimens reflects the numbers seen in biopsy material. ${ }^{15}$

\section{IMMUNOPEROXIDASE STAINING OF TISSUES}

The lung tissue samples were fixed in $10 \%$ formol saline, processed to paraffin wax, and sectioned to $3 \mu \mathrm{m}$ thickness. The sections were dewaxed, taken to Tris hydrochloric acid buffer, $(\mathrm{pH} 7.8)$ and endogenous peroxidase blocked with $0.1 \%$ hydrochloric acid in methanol for 30 minutes. After washing in buffer the sections were incubated for 45 minutes in mouse monoclonal antiserum to IgAl (antiserum M4D8) or IgA2 (SCAB1/2E2) which were prepared in the department of immunology, University of Birmingham. The characteristics of these antisera have been described elsewhere. ${ }^{16}$ After further washing the sections were incubated for 45 minutes in horseradish peroxidase conjugated rabbit antiserum to mouse IgG (department of immunology, Univer- sity of Birmingham). The peroxidase reaction was visualised by incubation with $1 \mathrm{mg} / 10 \mathrm{ml}$ 3,3'-diaminobenzidine in Tris hydrochloric acid $\overrightarrow{5}$

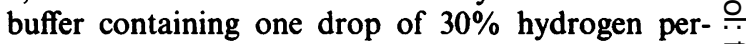
oxide. The sections were counterstained with hae- $\overrightarrow{\vec{F}}$ matoxylin, dehydrated, and mounted in synthetic medium.

QUANTITATION OF IGA POSITIVE CELLS

Tissue sections containing major first order bronchi $\cong$ were investigated. The numbers of cells stained posi- $ळ$ tively for $\operatorname{IgA} 1$ or $\operatorname{IgA} 2$ were counted in 10 separate $\overrightarrow{0}$ random fields on each section using an objective at a $\vec{\overrightarrow{ }}$ magnification of 40 . To prevent recounting of cells a $\vec{\omega}$ simple eyepiece graticule was used. The random fields counted included subepithelial seromucoid glands? and stroma.

Differences between cell counts in the subject $\vec{\circ}$ groups were tested using Student's $t$ test.

\section{Results}

The cells staining for IgA1 exceeded those staining for IgA2 in all groups of subjects (figure).

The numbers of cells positive for IgA2 were similar in the lung sections from chronic bronchitics (mean $\stackrel{\mathbb{D}}{-}$ (12) 51 cells) and bronchiectatics (mean (18) 56, but $\overrightarrow{0}$ both groups had significantly higher numbers tha $\stackrel{\infty}{\checkmark}$ the controls (mean (4.9) 24 two tailed p $<0.001$ Similarly, sections from subjects with chronic bros chitis and those with bronchiectasis had larger num-

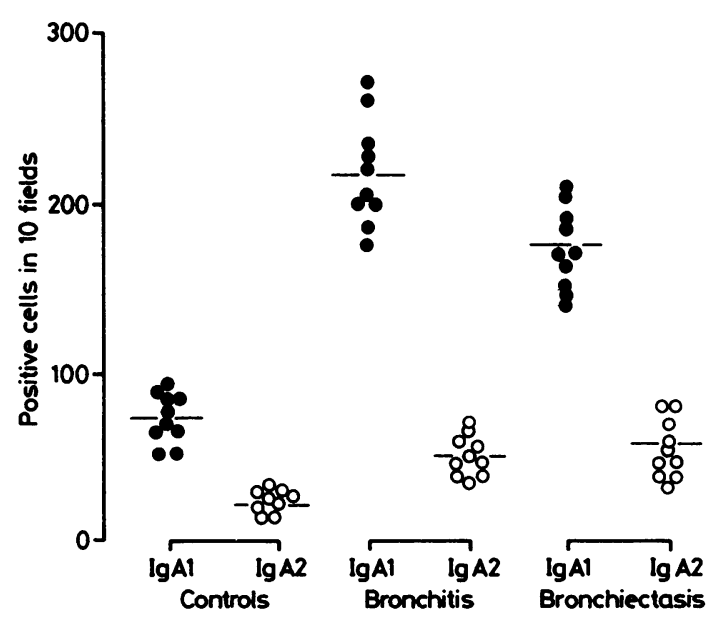

Figure Cells which stained for IgAl or IgA2 in necropsy lung tissue sections from 10 subjects who had died with chronic bronchitis, 10 who had bronchiectasis, and 10 who had no evidence of lung disease (controls). Each point represents number of positive cells counted in 10 microscope fields from one subject. Horizontal bars denote mean values. 
bers of $\operatorname{IgA} 1$ positive cells than the controls (mean (14.8) 73 cells, two tailed $p<0.001$ ), although the numbers of IgAl positive cells were higher in sections from chronic bronchitics (mean (32) 218) than those from the group of bronchiectatics (mean (24) 175 two tailed $\mathrm{p}<0.005$ ).

The proportion of $\operatorname{IgA} 2$ cells (per cent of total IgA positive cells) was similar in sections from the control group (mean (4.8) $24.8 \%$ ) and bronchiectatics (mean (4.2) $23.7 \%$ ) but significantly lower in the chronic bronchitics (mean (4.6) 19\% two tailed $p<0.001$ ).

The total numbers of IgA positive cells in sections from chronic bronchitics (mean (32) 269 cells) and bronchiectatics (mean (39) 230) were significantly higher than those of the control subjects (mean (17) 98 two tailed $\mathrm{p}<0.001$ ).

\section{Discussion}

Although IgA is thought to be important in protecting mucosal surfaces such as those of the lungs, its full role is uncertain. In particular, the biological importance of the higher proportions of the $\operatorname{IgA} 2$ subclass in mucosal secretions ${ }^{7}$ is not known, and functional differences between the subclasses are obscure. The IgA2 subclass is, however, resistant to proteolysis by the IgA proteases that are produced by many pathogenic bacteria. ${ }^{17}$ The stability of $\operatorname{IgA} 2$ in the presence of infection, when bacterial proteinases are likely to be released, would maintain its functional characteristics better than IgAl which would be more easily damaged by proteolytic cleavage.

In a small series (four samples) Andre et al ${ }^{18}$ reported that $27-33 \%$ of the IgA positive cells in human bronchus produced IgA2. Thus the lung, like other secretory tissue, contains a higher proportion of cells producing $\operatorname{IgA} 2$ than "non-secretory" lymphoid tissue. ${ }^{1920}$

In the present study we observed a proportion of IgA2:IgA1 cells in the normal human bronchus similar to that reported by Andre et al, ${ }^{18}$ and this seems to reflect the proportions of these IgA subclasses found in the lung secretions. ${ }^{7}$

Deficiency of serum and lung secretion IgA has been reported in subjects with chronic bronchitis and recurrent infections, including those associated with bronchiectasis. ${ }^{132122}$ Soutar $^{9}$ suggested that a deficiency of plasma cells producing $\operatorname{IgA}$ in the respiratory tract was a feature of subjects with fatal chronic bronchitis. We have been unable to confirm this observation, either in the group of bronchitics as a whole or in the four who had died of their disease. On the contrary, we observed significantly increased numbers of cells containing IgA in the bronchi of subjects with "fatal" or "incidental" chronic bronchitis.

The results are consistent with our previous obser- vations that most affected subjects seem to be capable of responding to infective exacerbations with an increase in IgA concentrations in their lung secretions. ${ }^{41213}$ Similarly, subjects who had died with another chronic lung disease, bronchiectasis, had increased numbers of cells containing $\operatorname{IgA}$ in the bronchi compared with subjects who had died without evidence of lung disease. The results of this study suggest, therefore, that most subjects with chronic obstructive lung disease do not have an associated general deficiency of cells producing IgA in the lung, although these conditions can be a consequence of systemic or local IgA deficiency in some subjects. ${ }^{13} 22$

The higher number of cells containing IgA in lungs of subjects who had died with chronic obstructive lung disease was represented by an increase in both IgA subclasses, and the proportion of $\operatorname{IgA} 2: \operatorname{IgA} 1$ cells was similar in those with bronchiectasis and controls. The subjects with chronic bronchitis, however, showed a preferential increase in the proportion of IgA1 cells compared with IgA2, resulting in a decreased proportion of the IgA2 cells.

The reasons for this observation are unknown. It would be valuable to determine whether the lung secretion concentrations of the $\operatorname{IgA}$ subclasses reflect the cell populations and if the increases lead to local secretion of more polymeric or secretory IgA. Further studies into the factors regulating the differential stimulus of plasma cells producing the IgA subclasses in the lungs are clearly indicated.

D Burnett is a British Lung Foundation/British Oxygen Company Centennial Fellow. RA Stockley is a Wolfson Research Fellow of the Royal College of Physicians of London.

We thank Miss P Nar for technical help and members of the department of immunology, University of Birmingham, particularly Drs $\mathrm{N}$ Ling, $\mathrm{R}$ Jefferis, and AR Bradwell for the antisera used in this study.

\section{References}

1 Burnett D. Immunoglobulins in the lung. Thorax 1986:41:337-44.

2 Merrill WW, Naegel GP, Olchowski JJ, Reynolds H. Immunoglobulin $G$ subclass proteins in serum and lavage fluid of normal subjects. Quantitation and comparison with immunoglobulins A and E. Am Rev Respir Dis 1985;131:584-7.

3 Newkirk MM, Klein MH, Katz. A, Fisher MM. Estimation of polymeric IgA in human serum: an assay based on binding of radiolabelled human secretory components with applications in the study of IgA nephropathy, monoclonal gammopathy and liver disease. J Immunol 1983;130:1176-81.

4 Stockley RA, Afford SC, Burnett D. Assessment of 7S and 11S immunogloblin A in sputum. Am Rev Respir Dis 1980;122:959-64.

5 Delacroix DL, Marchandise FX, Francis C, Sibille Y. Alpha-2 macroglobulin, monomeric and polymeric immunoglobulin A and immunoglobulin $\mathrm{M}$ in bronchoalveolar lavage. Am Rev Respir Dis 1985;132:829-35. 
6 Mostov KE. Blobel G. A transmembrane precursor for transcellular transport of polymeric immunoglobulins. $\mathrm{J} \mathrm{Biol} \mathrm{Chem}$ 1982:257:11816-21.

7 Delacroix DL, Dive C, Rambaud JC. Vacrman JP. IgA subclasses in various secretions and in serum. Immunology 1982:47:383-5.

8 Stockley RA, Mistry M, Bradwell AR, Burnetl D. A study of plasma proteins in the sol phase of sputum from patients with chronic bronchitis. Thorax 1979:34:777-82.

9 Soutar CA. Distribution of plasma cells and other cells containing immunoglobulin in the respiratory tract in chronic bronchitis. Thorax 1977;32:387-96.

10 Haimoto $H$, Nagura $H$, Imaizumi M, Watanabe K, lijima $S$. Immunoelectromicroscopic study on the transport of secretory IgA in the lower respiratory tract and alveoli. Virchows Arch (Pathol Anat) 1984;404:369-80.

11 Clarke CW. Aspects of serum and sputum antibody in chronic airways obstruction. Thorax 1976;31:702-7.

12 Stockley RA, Burnett D. Local IgA production in patients with chronic bronchitis: effect of acute respiratory infection. Thorax 1980:35:202-6.

13 Stockley RA, Burnell D, Afford SC. The immunological measurement of "free" secretory piece and its relationship to local IgA production. Clin Exp Immunol 1981:45:124-30.

14 Dunnill MS. Pulmonary pathology. Edinburgh: Churchill Livingstone, 1982.

15 Lenormand P, Crocker J. Distribution of IgAI and IgA2 subclasses in normal bone marrow trephines and in trephines infiltrated by IgA-producing multiple myeloma. J Clin Pathol 1987:40:200-5.

16 Farris MA, Hardie D. de Lange G. Jefferis R. Immunogenic and antigenic epitopes of immunoglobulins $\mathrm{X}$ : monoclonal anti- bodies specific for human $\operatorname{IgA}$, the $\operatorname{IgA} 1$ and $\operatorname{lgA} 2$ subclasses and an $\mathrm{nA} 2 \mathrm{~m}(2)$ iso-allotypic epitope. Vox Sang 1985:48:116-21.

17 Killian M, Mestecky J, Kulhavy R. Tomana M. Butler WT. IgA proteases from Haemophilus influenzae, Streptococcus pneu moniac. Neisseriac meningitis and Streptococcus sanguis: comparative immunochemical studies. $J$ Immunol 1980; 124:2596-600.

18 Andre $C$. Andre F. Fargier (C. Distribution of $\operatorname{IgA} I$ and $\operatorname{IgA} 2$ plasma cells in various normal tissues and in the jejunum of plasma IgA-deficient patients. Clin Exp Immunol 1978:33:327-31.

19 Crago SS, Kuttch WH. Moro I, Allansmith MR, Radl J. Haaijman JJ, Mestecky J. Distribution of IgAI-, IgA2- and $J$-chain containing cells in human tissues. $J$ Immunol 1984:132:16-18.

20 Kett K. Brandtzaeg P, Radl J. Haaijman JM. Different subclass distribution of IgA-producing cells in human lymphoid organs and various secretory tissues. $J$ Immunol 1986;136:3631-5.

21 Chipps BE. Talamo RC. Winkelstein JA. IgA deficiency, recurrent pneumonias and bronchiectasis. (hest 1978;73:519-26.

22 Umetsu DT. Ambrosino DM, Quinti I. Siber GR, Geta RS. Recurrent sino-pulmonary infection and impaired antibody response to bacterial capsular polysaccharide antigen in children with selective IgG-subclass deficiency. $N$ Engl J Med 1985:313:1247-51.

Requests for reprints to: Dr D Burnett, Clinical Teaching Block, The General Hospital, Steelhouse Lane, Birmingham B4 6NH, England. 